\title{
THE IMPACT OF SERVICE QUALITY ON USER SATISFACTION: A CASE STUDY OF SELECTED PUBLIC LIBRARIES IN BANGLADESH
}

\author{
Md. Amanullah ${ }^{1} *$ \\ ${ }^{1}$ Professor, \\ School of Business, \\ Ahsanullah University of Science and \\ Technology, \\ 141-142 Love Road, Tejgaon, \\ Dhaka1208, \\ Bangladesh.
}

\author{
Mahamudul Hasan ${ }^{2}$ \\ ${ }^{2}$ Assistant Professor, \\ Department of Marketing, \\ Faculty of Business Administration and \\ Management, \\ Patuakhali Science \& Technology University, \\ Dumki, Patuakhali 8602, \\ Bangladesh
}

\author{
Md.Hafez ${ }^{3}$ \\ ${ }^{3}$ Assistant Professor, \\ School of Business, \\ Ahsanullah University of Science and Technology, \\ 141-142 Love Road, Tejgaon, \\ Dhaka1208, \\ Bangladesh.
}

Article DOI: https://doi.org/10.36713/epra6218

\begin{abstract}
The objective of the study is to examine the impact of service quality dimensions on user satisfaction of the public library in Bangladesh. A structured questionnaire had been developed and distributed among 150 respondents who are taking public library services from Barisal and Patuakhali district. Convenience Sampling method was applied to collect primary data. Several hypotheses have been extracted from the conceptual framework and are tested using multiple regression analysis. Findings of the study showed that service quality dimensions have a certain degree of relationship with public library user satisfaction. It is also shown that tangibles are the most dominant predictors among five (5) significant predictors which mostly lead to public library user satisfaction. Besides, results also show empathy, and the assurance dimension plays a significant role in user satisfaction. Therefore, these findings will beneficial for those who are solely responsible for public library management and can get an idea to improve the overall service quality of public libraries to provide a high degree of satisfaction.
\end{abstract}

KEYWORDS: SERVQUAL, Tangibles, Responsiveness, Reliability, Assurance, Empathy, Satisfaction 


\subsection{INTRODUCTION}

The modern age is the age of information. It plays a critical role in the overall development of human beings (Terhile \& Anthanisus, 2013). Public libraries are service-oriented institutions that contribute to society by delivering sources of knowledge and updated information for the readers. The primary goal of the public library is to satisfy the users through quality library services. Thakuria (2007) said that service quality is a matchmaker of expectations and perceptions of the library users. Service quality is the extent of delivery the excellence in the resources and library services to the users to gain a higher level of satisfaction (Partap, 2019). The public library is diverse from the academic library such as an academic library in terms of the services that provide information to the general public. In Bangladesh, every district has public libraries but in our study, we just focus on the public library in Barisal and Patuakhali region. The public library in Barisal and Patuakhali delivers different educational services such as books, articles, journals, and other relevant connected to reading activities. Many studies have been conducted to investigate the impact of service quality on user satisfaction in the context of university academic libraries in Bangladesh by Alam, 2020; Hossain \& Islam, 2012. Unfortunately, very few studies have been conducted in Bangladesh related to public library user satisfaction. Therefore, this study is an endeavor to examine the impact of service quality on public library user satisfaction.

Specifically, the current study aims to accomplish these objectives by answering the following research questions:

1. How do service quality dimensions (Tangibles, Responsiveness, Reliability, Assurance, Empathy) influence user satisfaction of public libraries in Bangladesh?

2. Which dimensions have more impact on the user satisfaction of public libraries in Bangladesh?

3. What will be the strategies to enhance the user satisfaction of public libraries in Bangladesh?

This study has been organized as follows: the first part includes a review of literature and hypotheses development. The second part explains the methodology and conceptual framework for this study. The third part shows the data analysis and the results of the study. Finally, the study concludes with a discussion of the theoretical and managerial implications along with the conclusion.

\subsection{LITERATURE REVIEW AND HYPOTHESES DEVELOPMENT Measuring Service Quality of Public Libraries in Bangladesh}

Service quality can be defined as the overall assessment of the services by the users. Service quality depends on how much a service is to meet up the consumer's expectations. Wang \& Shieh (2006) stated that service quality is the difference between customers' hope and actual services provided by the service firms. Hernon and Altman (2010) stated that users' assessment of library services is a well-known concept and recommended eleven questions for evaluating library services: how much, how many, how economical, how prompt, how accurate, how responsive, how well, how valuable, how reliable, how courteous, and how satisfied. Service quality can be measured in various ways: SERVQUAL, WebQUAL, SiteQUAL, Post Service Rating, Customer Effort Score (CES), and Documentation Analysis. Library professionals should be conscious of users' beliefs in providing quality services (Shoeb, 2011).

Traditionally the quality of a library has been defined in terms of its collection of books or assessed by the size of the library's holdings and various counts of its usage (Shoeb, 2011). But now a day's it has been considered the obsolete idea of measurement. "SERVQUAL," can be an alternative approach to measure the service quality of library services (Hossain, 2012). Kiran (2010) asserted that SERVQUAL consists of five dimensions that have been reliably categorized by users for measuring the service quality irrespective of the service industry. This model has been widely used to evaluate library service quality among academic, public, and special libraries (Hernon, 2002). Thus, SERVQUAL dimensions are selected to measure public libraries' service quality associated with the user's satisfaction with its services.

Parasuraman et al. (1988) developed SERVQUAL for assessing the service quality based on the disconfirmation paradigm known as the gap model. In the beginning, the SERVQUAL scale had ten dimensions and then redefined it into five dimensions (Parasuraman et al. 1988). Reliability - The ability to accurate service delivery, Assurance - the knowledge and courtesy of employees, Tangibles - the appearance of the building, website, equipment, and employees; Empathy - the employee's caring attitude and individualized attention, Responsiveness - ability to provide quick service speedy service.

Ahmed and Shoeb (2009) applied SERVQUAL instruments for evaluating the service quality of academic libraries in Bangladesh. Likewise, Hossain \& 
Islam (2012) used SERVQUAL instruments for understanding the perceived service quality and satisfaction of the Dhaka University public Library.

\section{Relationship between Service Quality and} User Satisfaction

Excellent service quality provides a high level of customer satisfaction (Nadiri et al., 2009). Zeithman et al. (2018) defined that user satisfaction derives from a product or service's capability to satisfy necessary needs and expectations. Marshall et al. (1998) stated that service quality could be accomplished by critically thinking about complete services that satisfy users' needs. The public library.users are high when the service delivered is of prodigious value, improving quality of life and gratifying a crucial need for most library users. (Usherwood and Sobczyk, 1997).

Hoyer and MacInnis (2001) affirmed that satisfaction is connected with feelings of recognition, pleasure, aid, joy, and happiness. Mairaj and Naseer (2013) identified that users were satisfied with the services and resources provided by the Punjab Institute of Cardiology Library, especially library assortment and its arrangement, reference and exchange services, staff assertiveness, as well as the cooling and heating structure of the library. On the other hand, Ahmed (2017) said that four SERVQUAL dimensions, namely empathy, responsiveness, assurance, and reliability, can significantly influence user's satisfaction with library services.

Alam (2020) revealed that tangible facilities and staff responsiveness of the library significantly influenced user satisfaction. Twum et al. (2020) stated that all the service quality dimensions positively correlate with library user satisfaction. Moses et al. (2016) showed that service quality has a significant positive impact on library user satisfaction. Suki \& Suki (2013) affirmed that public library and service quality user satisfaction is highly correlated. Based on the discussion, the following hypotheses are proposed: H1. Tangibles of the public library have a significant impact on user satisfaction.

H2. Responsiveness of library staff has a significant impact on user satisfaction.

H3. Reliability of library services has a significant impact on user satisfaction.

H4. Assurance of library staff has a significant impact on user satisfaction.

H5. Empathy of Liberians has a significant impact on user satisfaction.

\section{METHODS}

This study is descriptive and quantitative research because the user's attitude and perception of tangibles, Responsiveness, reliability, Assurance, and empathy, and their impact on user satisfaction are measured in this study.

\section{Sampling Design}

This research is covered by the library services used by the library users. The sampling unit contains both male and female students who use library services. The sampling area comprises Patuakhali Science and Technology University's central library, University of Barisal's central library, Divisional public library in Barisal. In this study, the sample size was 150 . Noprobabilistic convenience sampling technique was used to collect primary data in this research because it is an easy and convenient approach to collect data (Malhotra, 2017).

Questionnaire Design and Data Collection

To accomplish the purposes of this study both primary and secondary data have been used. Secondary data has been collected from journals and books. Primary data is collected from the library users through a self-administered questionnaire. Considering the study's nature, 5-point Likert Scale was applied where Strongly Disagree $=1$, Disagree $=2$, Neutral=3, Agree $=4$, and Strongly agree $=5$ are used to collect data about the impact of service quality on library user satisfaction. A structured questionnaire was designed in two parts. Part-I, to pinpoint respondents' specific demographic information, including gender, age, education, frequency of visit, and part-II- contains 26 influential variables of service quality and library users' user satisfaction.

\section{Data Analysis}

The data were analyzed using the Statistical Package of Social Science (SPSS, 16.0). In this study, both the descriptive and inferential analysis techniques, including reliability statistics (Cronbach Alpha), Mean, Standard Deviation, and Multiple Regression Analysis were used to achieve these research objectives.

\section{Conceptual Model}

A conceptual model has been recommended based on previous literature discussed above. SERVQUAL dimensions for measuring service quality namely tangibles, Responsiveness, reliability, Assurance, and empathy are independent variables and library user satisfaction is a dependent variable for this research. 


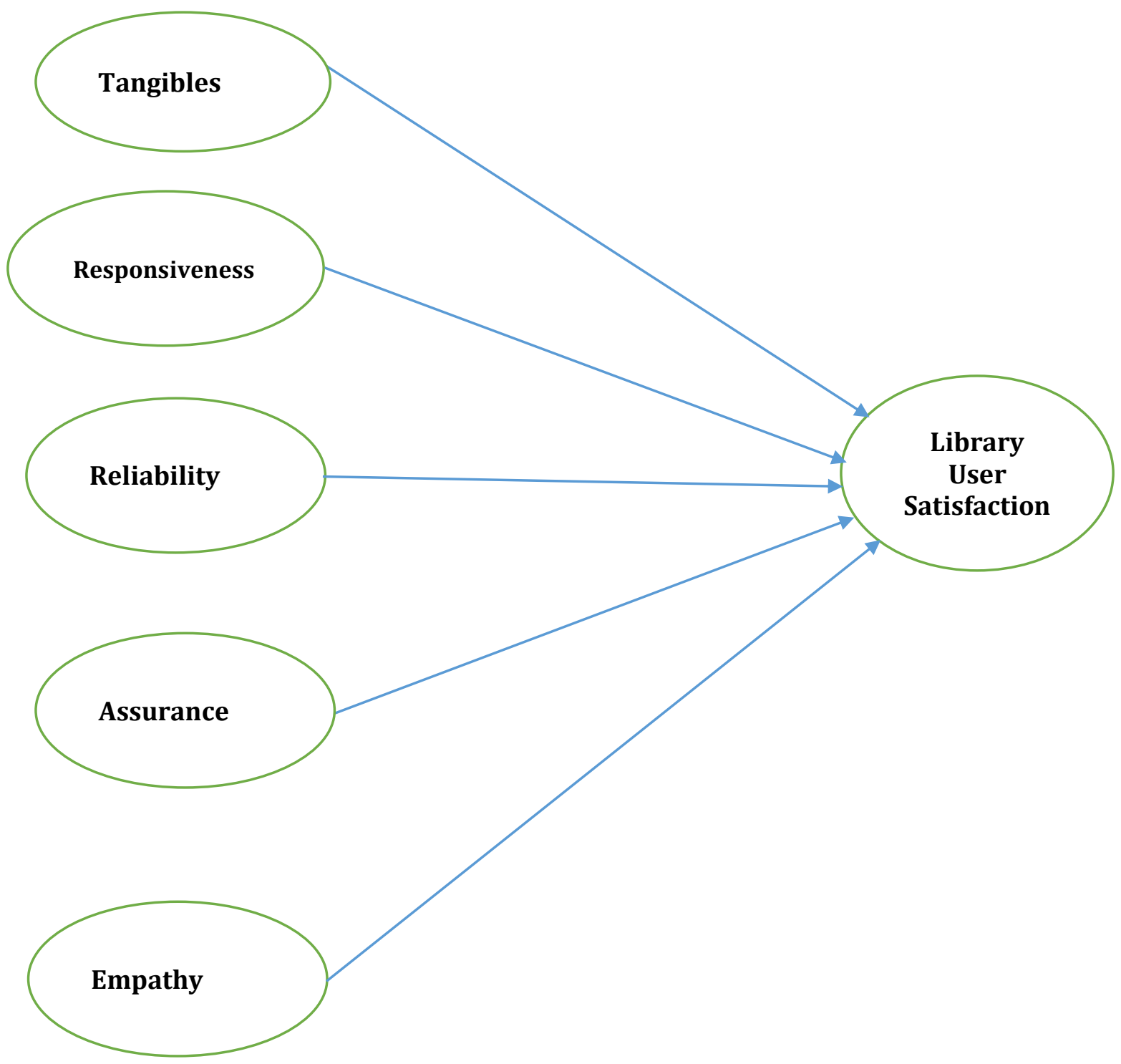

Figure 1. Conceptual Model

RESULTS

Reliability of Scale :To determine the scale reliability of the questionnaire, Cronbach's Alpha was calculated for all the constructs. The results of the Cronbach's Alpha is presented as follows: 


\begin{tabular}{|c|c|c|c|}
\hline Name & $\begin{array}{l}\text { No of } \\
\text { Items }\end{array}$ & Statements & $\begin{array}{l}\text { Cronbac } \\
\text { h's } \\
\text { Alpha }\end{array}$ \\
\hline Tangibles & 8 & $\begin{array}{l}\text { 1. There is a sufficient number of periodicals. } \\
\text { 2. There is a sufficient number of books. } \\
\text { 3. The environment is clean. } \\
\text { 4. There is a sufficient number of study rooms. } \\
\text { 5. There is a sufficient number of computers } \\
\text { 6. Study areas are comfortable. } \\
\text { 7. The lighting quality is fine. } \\
\text { 8. The overall reading atmosphere is good. }\end{array}$ & .804 \\
\hline Reliability & 4 & $\begin{array}{l}\text { 1. The collections are timely. } \\
\text { 2. The collections are shelved accurately. } \\
\text { 3. The loan and return records are accurate. } \\
\text { 4. The staff can answer questions accurately. }\end{array}$ & .568 \\
\hline Responsiveness & 3 & $\begin{array}{l}\text { 1. Library staff tries their best to answers. } \\
\text { 2. Library staff actively and aggressively provides } \\
\text { services. } \\
\text { 3. Library staff helps users to locate and retrieve } \\
\text { information. }\end{array}$ & .793 \\
\hline Assurance & 4 & $\begin{array}{l}\text { 1. The classifications fit in with all subjects. } \\
\text { 2. Library staffs are approachable and welcoming. } \\
\text { 3. The library staff is friendly and courteous. } \\
\text { 4. Library staff is aware of every service item. }\end{array}$ & .664 \\
\hline Empathy & 4 & $\begin{array}{l}\text { 1. Library staffs provide individual attention to users. } \\
\text { 2. Library staffs provide general help to students for } \\
\text { research. } \\
\text { 3. Library staffs listen to the query quietly. } \\
\text { 4. Deal with users in a caring fashion }\end{array}$ & .502 \\
\hline User satisfaction & 3 & $\begin{array}{l}\text { 1. I am satisfied with the service quality of the library. } \\
\text { 2. I am satisfied with the service of the library staff. } \\
\text { 3. I am satisfied with the library facilities. }\end{array}$ & .761. \\
\hline
\end{tabular}


Table 2. Demographic Profile of the Respondents

\begin{tabular}{llll} 
Variable & Category & Frequency & Percentage \\
\hline Gender & Male & 86 & $57 \%$ \\
& & & \\
Level of Education & Female & 64 & $43 \%$ \\
& Bachelor & 118 & $79 \%$ \\
& Master & 21 & $14 \%$ \\
& PhD & 0 & $0 \%$ \\
Frequency of Visit & Others & 11 & $7 \%$ \\
& Daily & 49 & $33 \%$ \\
& Weekly & 69 & $46 \%$ \\
\hline
\end{tabular}

Table -2 shows the public library user's demographics profile, which encompasses gender, level of education, and frequency of visit. From these results, it has been shown that male library users are dominant $(59 \%)$ compared to female users $(43 \%)$. In education, more than two-thirds of library users have bachelor's degree whereas library users with a master's degree are $14 \%$. Moreover, the weekly visit of library users is prominent (46\%) compared to daily (33\%) and monthly (21\%) visitors of public libraries.

Table 3. Regression Analysis and Hypothesis Testing

\begin{tabular}{|c|c|c|c|c|c|c|}
\hline Model & $\mathbf{F}$ & $\begin{array}{l}\text { Standardi } \\
\text { zed } \\
\text { Coefficien } \\
\text { ts Beta }\end{array}$ & t-value & R2 & $\begin{array}{l}\text { Adjusted } \\
\text { R2 }\end{array}$ & $\begin{array}{l}p \\
\text { value }\end{array}$ \\
\hline $\begin{array}{l}\text { Overall service quality } \longrightarrow \text { Library user } \\
\text { satisfaction }\end{array}$ & & & & .629 & .616 & .000 \\
\hline $\begin{array}{l}\text { Tangibles } \longrightarrow \text { Library user } \\
\text { Satisfaction }(\mathrm{H} 1)\end{array}$ & 159.458 & .947 & 12.628 & .524 & .520 & .000 \\
\hline $\begin{array}{l}\text { Responsiveness } \longrightarrow \text { Library user } \\
\text { Satisfaction }(\mathrm{H} 2)\end{array}$ & 159.458 & .608 & 9.850 & .401 & .397 & .000 \\
\hline $\begin{array}{l}\text { Reliability } \longrightarrow \text { Library user } \\
\text { Satisfaction (H3) }\end{array}$ & 159.458 & .745 & 7.325 & .270 & .265 & .000 \\
\hline $\begin{array}{l}\text { Assurance } \longrightarrow \text { Library user } \\
\text { Satisfaction }(\mathrm{H} 4)\end{array}$ & 159.458 & .827 & 10.471 & .431 & .427 & .000 \\
\hline $\begin{array}{l}\text { Empathy } \longrightarrow \text { Library user } \\
\text { Satisfaction (H5) }\end{array}$ & 159.458 & .864 & 8.094 & .311 & .306 & .000 \\
\hline
\end{tabular}


From the above table 3 , It is shown that the coefficient of multiple determination is $\mathrm{R}^{2}=.629$. This means that 62.9 percent variations in the dependent variable i.e. library user satisfaction are described by independent variables that include tangibles, reliability, Responsiveness, Assurance, empathy and the remaining $37.1 \%$ can be attributed to other factors that are not studied. The value of adjusted $\mathrm{R}^{2}(61.6 \%)$ is very close to $R^{2}(62.9)$ which indicates the addition of more independent variables contributes to explaining the level of library user satisfaction.

Table 3 also illustrates that showed that tangibles, reliability, Responsiveness, Assurance, empathy are significant predictors to measure library user satisfaction. Therefore, Hypotheses 1, Hypotheses 2, Hypotheses 3, Hypotheses 4 Hypotheses 5 are supported because all $\mathrm{P}$-value is less than .05 $(.000<.05)$. Among all predictors, tangibles have the most significant impact on library user satisfaction where the Beta value for tangibles is .947.

\section{DISCUSSION}

The main objective of this study was to investigate the impact of service quality on public library user satisfaction. Results showed that tangibles, reliability, Responsiveness, Assurance, empathy have a significant positive relationship with library user satisfaction which is consistent with the previous findings (Ahmed, 2017; Alam, 2020; Ahmed, 2017; Podbrežnik, 2015; Hossain \& Islam, 2012; Manjunatha, \& Shivalingaiah, 2004). Tangibles are ranked as the most important dimension in this study (See Table 3) which is supported by Alam, 2020. This result indicates that library user satisfaction largely depends on the sufficient number of periodicals, books, and computers. Besides clean, well-furnished, and comfortable reading atmosphere contributes to public library user satisfaction. Empathy and Assurance are also ranked the second and third most important dimension in this study (See Table 5) which is supported by Ahmed, 2017; Suki \& Suki, 2013. These findings have also suggested that public library users feel satisfied when they get an individualized caring attitude from the librarian along with approachable, welcoming, friendly, and courteous behavior from library staff.

\section{CONCLUSION}

The prime objective of this research is to examine the impact of service quality dimensions on public library user satisfaction in Bangladesh. The data is collected from the public library user in Patuakhali Science and Technology University's central library, University of Barisal's central library, Divisional public library in Barisal. The sample size was 150 in this study. The results have shown that tangibles, empathy, and Assurance are the most significant predictors in determining public library user satisfaction. Based on the findings, the government and the library authorities should focus on state-of-the-art tangible facilities in the library as well as ensure welcoming and individualized caring and friendly behavior for the public library users.

\section{REFERENCES}

1. Ahmed, S. (2017). Service quality satisfaction: a comparative cross-sectional study of public and private university librarians in Pakistan. Libri, 67(4), 313-325. https://doi.org/10.1515/libri-20170011

2. Ahmed, S. Z., \& Shoeb, Z. H. (2009). Measuring service quality of a public university library in Bangladesh using SERVQUAL. Performance measurement and metrics. 10 (1), $17-$ 32.https://doi.org/10.1108/14678040910949666

3. Alam, M. J. (2020). Effects of service quality on satisfaction in Eastern University Library, Bangladesh. IFLA Journal, 0340035220959099. https://doi.org/10.1177/0340035220959099

4. Hernon, P. (2002). Quality: new directions in the research. The journal of academic librarianship, 28(4), 224-231. https://doi.org/10.1016/S00991333(02)00286-0

5. Hernon, P., \& Altman, E. (2010). Assessing service quality: Satisfying the expectations of library customers. American Library Association.

6. Hossain, M. J., \& Islam, A. (2012). Understanding perceived service quality and satisfaction. Performance Measurement and Metrics. 13(3),169182. https://doi.org/10.1108/14678041211284713

7. Hoyer, W. D. and D. J. MacInnis (2001), "Consumer Behavior", 2nd Edition, HoughtonMifflin, Boston, MA.

8. Kiran, K. (2010). Service quality and customer satisfaction in academic libraries. Library Review. 59 (4), $\quad$ pp. 261-273. https://doi.org/10.1108/00242531011038578

9. Mairaj, M. I., \& Naseer, M. M. (2013). Library services and user satisfaction in developing countries: a case study. Health Information \& Libraries Journal, 30(4), 318-326. https://doi.org/10.1111/hir.12038

10. Malhotra, N. K., Nunan, D., \& Birks, D. F. (2017). Marketing research: An applied approach. Pearson Education Limited.

11. Manjunatha, K., \& Shivalingaiah, D. (2004). Customer's perception of service quality in libraries. Annals of library and information studies, 51(4), 145-151.

12. Marshall, G. W., Baker, J., \& Finn, D. W. (1998). Exploring internal customer service quality. Journal of Business \& Industrial Marketing.13 
(4/5),

381-392.

https://doi.org/10.1108/08858629810226681

13. Moses, C., Olaleke, O., Akinbode, M., Agboola, M. G., Olokundun, A. M., \& Aka, D. (2016). Perceived service quality and user satisfaction in library environment. Asian Journal of Information Technology, 15(1), 18-25.

14. Nadiri, H., Kandampully, J., \& Hussain, K. (2009). Zone of tolerance for banks: a diagnostic model of service quality. The Service Industries Journal, 29(11), 1547-1564 https://doi.org/10.1080/02642060902793425

15. Parasuraman, A., Zeithaml, V. A., \& Berry, L. L. (1988). Servqual: A multiple-item scale for measuring consumer perc. Journal of retailing, 64(1), 12.

16. Partap, B. (2019). A Review of Service Quality Assessment of Library and Information Centres. Library Philosophy and Practice, 1-17.

17. Podbrežnik, I. (2015). Using Servqual for public Library Service Quality Assessment. Zbornik Radova-Asocijacija informacijskih stručnjaka, bibliotekara, arhivista i muzeologa (BAM), (08), 51-63.

18. Shoeb, Z. H. (2011). Identifying service superiority, zone of tolerance and underlying dimensions. Library Review. 60(4), 293-311. https://doi.org/10.1108/00242531111127857

19. Suki, N., \& Suki, N.M. (2013). Service Quality vs. Customer Satisfaction: Perspectives of Visitors to a Public University Library. World Academy of Science, Engineering and Technology, International Journal of Social, Behavioral, Educational, Economic, Business and Industrial Engineering, 7, 338-342.

20. Terhile, B. F., \& Anthanisus, Y. A. (2013). A comparative study on user satisfaction with the management of library services in three academic libraries in Benue State-Nigeria. Journal of Studies in Social Sciences, 6(1).23-30

21. Thakuria, P. K. (2007). Concept of quality in library services: an overview. Accessed November, 2020. http://hdl.handle.net/1944/1370.

22. Twum, K. K., Adams, M., Budu, S., \& Budu, R. A. A. (2020). Achieving university libraries user loyalty through user satisfaction: the role of service quality. Journal of Marketing for Higher Education, 1-19. https://doi.org/10.1080/08841241.2020.1825030

23. Usherwood, R. P. B., \& Sobczyk, G. (1997). What happens when a public library service closes down?.

24. Library Management. 18(1), 59-64. https://doi.org/10.1108/01435129710157752

25. Wang, I. M., \& Shieh, C. J. (2006). The relationship between service quality and customer satisfaction: the example of CJCU library. Journal of Information and optimization Sciences, 27(1), 193-
209. https://doi.org/10.1080/02522667.2006.10699686

26. Zeithaml, V. A., Bitner, M. J., \& Gremler, D. D. (2018). Services marketing: Integrating customer focus across the firm. McGraw-Hill Education. 